\title{
TIME TO ELIMINATE THE PENNY FROM THE U.S. COINAGE SYSTEM:
}

\section{NEW EVIDENCE}

\author{
Robert Whaples \\ Wake Forest University
}

\section{INTRODUCTION}

In "Eliminating the Penny from the U.S. Coinage System: An Economic Analysis," Raymond Lombra [2001] notes several adverse effects of eliminating the penny. He argues that elimination of the penny will a) impose a sizeable and regressive "rounding tax" on consumers, b) boost the inflation rate and federal government outlays, c) drive up firms' costs and squeeze their profits, and d) deprive the government of considerable seigniorage. In this note I reexamine these findings in light of new evidence and conclude that it is probably time for the U.S. Mint to cease minting pennies.

\section{NEW FINDINGS ON THE "ROUNDING TAX"}

The heart of Lombra's analysis is his estimate of the losses to consumers if the penny were eliminated and cash prices were rounded up or down to the nearest nickel. Using data from the price book of a typical convenience store, he shows that the last digit for over eighty percent of prices is a nine. Simulating 5000 purchases of from one to three items across the full spectrum of the 3585 items in the price book, he estimates that 60 percent of the transactions result in rounding upward if three items are purchased and up to 93 percent are rounded upward if one or two items are bought. As a lower bound, if half of the 106 billion annual consumer transactions were made with cash and 60 percent were rounded upward, consumers would collectively lose $\$ 318$ million per year. As an upper bound, if 83 percent of transactions use cash and 93 percent have prices rounded upward, the loss to consumers would be $\$ 818$ million annually.

The first limitation of this analysis is that it is unknown how many items (and in what combinations) consumers purchase from convenience stores. The "rounding tax" is lower as more items are purchased, but information on how many items are purchased was unavailable to Lombra and many purchases involve more than three items. More problematically this calculation assumes that all such transactions are not taxed. Chande and Fisher's [2003] simulations show that the "rounding tax" essentially disappears in Canada where all items are taxed. Convenience stores' goods are taxed in the United States, too. According to the Federation of Tax Administra-

Robert Whaples: Department of Economics, Wake Forest University, Winston-Salem, NC 27109. E-mail: whaples@wfu.edu.

Eastern Economic Journal, Vol. 33, No. 1, Winter 2007 
tors [2006], only five U.S. states (Alaska, Delaware, Montana, New Hampshire, and Oregon), with 2.5 percent of the U.S. population, have no sales tax. On the other hand, many items purchased at convenience stores are food items which are exempt from sales tax in most states. States exempting food from sales tax made up 71.7 percent of the U.S. population in $2006 .^{1}$

Given these complexities, it is unclear how rounding current prices would affect American consumers. Fortunately, I was able to obtain data on nearly 200,000 individual transactions from a convenience store chain that operates in seven states in the eastern U.S. - Alabama, Georgia, North Carolina, Pennsylvania, South Carolina, Tennessee, and Virginia. ${ }^{2}$ The general sales tax and food sales tax rates for these states are given in Table 1.

TABLE 1

Sales Tax Rates in Seven States (July 2005)

\begin{tabular}{lcc}
\hline State & Sales Tax Rate & Sales Tax on Food \\
\hline Alabama & 4 & 4 \\
Georgia & 4 & 0, but subject to local sales tax \\
North Carolina & 4.5 & 0, but subject to local sales tax \\
Pennsylvania & 6 & 0 \\
South Carolina & 5 & 5 \\
Tennessee & 7 & 6 \\
Virginia & 5 & 3.5 \\
\hline
\end{tabular}

Table 2 reports the gains and losses during a one-week period to this chain's consumers if their bills were to be rounded to the nearest nickel. The first column reports all transactions, including both cash and non-cash transactions. The second column reports all transactions on which sales tax was charged - thus excluding gasoline-only (and some other) purchases. The data set mixes together cash and noncash transactions, but there are a couple of close proxies for cash transactions in the third and fourth columns of Table 2 . The best proxy is probably transactions in which change was returned. ${ }^{3}$ Another proxy is transactions in which the total amount paid is less than $\$ 5$.

As the table demonstrates, the total effect on buyers and sellers from rounding current totals to the nearest nickel would be very, very small. Across twenty stores and 185,714 transactions, consumers win - but the total gain to customers is only $\$ 105.60$ or about one-twentieth of a cent per transaction. This amounts to a tiny loss of 75.4 cents per store per day. In every state the results are similar. In a few states consumers lose a hair, in the rest they gain a hair or two. The largest margin is a customer gain of about one-eighth of a cent per sale in North Carolina.

Pennsylvania may be the most nationally-representative of these states, since it does not charge sales tax on food. In Pennsylvania, customers do lose from rounding, but the losses are not more than half a cent per transaction as Lombra's simulation implies. Consumers' losses in Pennsylvania add up to an infinitesimal $\$ 1.79$ or one cent for every 67 transactions.

Lombra's analysis focuses on cash transactions, but these don't appear to differ from overall transactions. For the transactions in which change was returned to 
the customer - almost all of which would have been cash transactions ${ }^{4}$ - customers collectively would have gained $\$ 23.82$ from rounding to the nearest nickel or about one-fortieth of a penny per transaction. Likewise, customers would win marginally from rounding of purchases that come out to less than $\$ 5$, with a collective gain of $\$ 28.87$ or $1 / 26^{\text {th }}$ of a cent per transaction. The bottom line is that rounding would have essentially no effect on consumers or sellers as a group, if these transactions are indicative. The "rounding tax" is effectively zero.

TABLE 2

Customers' Gains and Losses from Rounding to the Nearest Nickel

\begin{tabular}{lrccrrr}
\hline $\begin{array}{c}\text { State } \\
\text { \# of stores) }\end{array}$ & \multicolumn{3}{c}{$\begin{array}{c}\text { All Transactions: } \\
\text { Column 1 }\end{array}$} & \multicolumn{3}{c}{$\begin{array}{c}\text { Transactions with Sales Tax } \\
\text { Column 2 }\end{array}$} \\
\hline & $\begin{array}{c}\text { Gain/Loss to } \\
\text { Customers }\end{array}$ & $\begin{array}{c}\text { Total } \\
\text { Transactions }\end{array}$ & $\begin{array}{c}\text { Gain/Loss } \\
\text { per } \\
\text { Transaction }\end{array}$ & $\begin{array}{c}\text { Gain/Loss to } \\
\text { Customers }\end{array}$ & $\begin{array}{c}\text { Total } \\
\text { Transactions }\end{array}$ & $\begin{array}{c}\text { Gain/Loss } \\
\text { per } \\
\text { Transaction }\end{array}$ \\
\hline Alabama (1) & $+\$ 6.12$ & 10,730 & +0.057 cents & $+\$ 0.51$ & 5540 & +0.009 cents \\
Georgia (4) & $+\$ 30.18$ & 43,885 & +0.069 cents & $+\$ 13.37$ & 25,762 & +0.052 cents \\
North Carolina (5) & $+\$ 44.24$ & 33,870 & +0.131 cents & $+\$ 34.69$ & 22,681 & +0.153 cents \\
Pennsylvania (1) & $-\$ 1.79$ & 12,034 & -0.015 cents & $+\$ 8.91$ & 6080 & +0.147 cents \\
South Carolina (4) & $+\$ 19.98$ & 41,275 & +0.048 cents & $-\$ 4.52$ & 24,355 & -0.019 cents \\
Tennessee (1) & $+\$ 3.16$ & 10,039 & +0.031 cents & $+\$ 1.06$ & 6501 & +0.016 cents \\
Virginia (4) & $+\$ 3.71$ & 33,881 & +0.011 cents & $-\$ 11.89$ & 17,198 & -0.069 cents \\
All Locations (20) & $+\$ 105.60$ & 185,714 & +0.057 cents & $+\$ 42.13$ & 108,117 & +0.039 cents \\
Akron Drive & $+\$ 6.29$ & 7001 & +0.090 cents & $+\$ 4.93$ & 5255 & +0.094 cents \\
Stratford Road & +7.46 & 6591 & +0.113 cents & $+\$ 5.40$ & 4223 & +0.128 cents \\
\hline
\end{tabular}

\begin{tabular}{lrrrrrr}
$\begin{array}{c}\text { State } \\
\text { \# of stores) }\end{array}$ & \multicolumn{2}{c}{$\begin{array}{c}\text { Change-Returned Transactions } \\
\text { Column 3 }\end{array}$} & $\begin{array}{c}\text { Transactions Less Than } \$ 5 \\
\text { Column 4 }\end{array}$ \\
\hline & $\begin{array}{c}\text { Gain/Loss to } \\
\text { Customers }\end{array}$ & $\begin{array}{c}\text { Total } \\
\text { Transactions }\end{array}$ & $\begin{array}{c}\text { Gain/Loss } \\
\text { per } \\
\text { Transaction }\end{array}$ & $\begin{array}{c}\text { Gain/Loss to } \\
\text { Customers }\end{array}$ & $\begin{array}{c}\text { Total } \\
\text { Transactions }\end{array}$ & $\begin{array}{c}\text { Gain/Loss } \\
\text { per } \\
\text { Transaction }\end{array}$ \\
\hline Alabama (1) & $+\$ 1.44$ & 5550 & +0.026 cents & $+\$ 0.47$ & 3437 & +0.014 cents \\
Georgia (4) & $+\$ 9.13$ & 23,576 & +0.039 cents & $+\$ 11.62$ & 18,530 & +0.063 cents \\
North Carolina (5) & $+\$ 19.29$ & 18,641 & +0.103 cents & $+\$ 26.53$ & 15,775 & +0.168 cents \\
Pennsylvania (1) & $-\$ 4.84$ & 7245 & -0.067 cents & $-\$ 2.88$ & 5282 & -0.055 cents \\
South Carolina (4) & $+\$ 1.09$ & 23,304 & +0.005 cents & $-\$ 5.57$ & 17,064 & -0.033 cents \\
Tennessee (1) & $+\$ 2.06$ & 6177 & +0.033 cents & $+\$ 3.06$ & 4383 & +0.070 cents \\
Virginia (4) & $-\$ 4.35$ & 16,029 & -0.027 cents & $-\$ 4.36$ & 11,864 & -0.037 cents \\
All Locations (20) & $+\$ 23.82$ & 100,552 & +0.024 cents & $+\$ 28.87$ & 76,355 & +0.038 cents \\
Akron Drive & $+\$ 1.93$ & 4626 & +0.042 cents & $+\$ 3.78$ & 3608 & +0.105 cents \\
Stratford Road & $+\$ 3.88$ & 3775 & +0.103 cents & $+\$ 3.48$ & 2807 & +0.124 cents \\
\hline
\end{tabular}

Again, in both of these cases customers in Pennsylvania would have lost a few dollars - $\$ 4.84$ on change-returned transactions and $\$ 2.88$ on purchases of less than $\$ 5$ - but again the losses are very small -0.067 and 0.055 cents per transaction, respectively. Slicing the data more thinly reveals exactly which Pennsylvania customers would lose. Losses on purchases of less than $\$ 5$ total $\$ 2.88$, but losses on the 571 purchases of less than $\$ 1$ make up more than all of this amount $-\$ 4.91$. Customers buying a single untaxed item whose price is less than $\$ 1.00$ and whose price ends in the 9 digit are the "big" losers. Those spending less than one dollar have a loss rate of 0.86 cents per transaction, but their collective loss is less than $\$ 5$ per week at a store 
processing over 12,000 transactions per week. These customers are fairly atypical, making up 4.7 percent of purchases.

Lombra's conclusion that the tax would be regressive is also not supported by these data. The bottom rows of Table 2 compare two stores in Winston-Salem, North Carolina. The store on Stratford Road is in a fairly affluent section of the city, while the store on Akron Drive is in the poorer section of town. The rounding estimates are essentially the same in both settings - with customers coming out slightly ahead in both locations. ${ }^{5}$

\section{IMPACT ON INFLATION}

Lombra's second major contention is that rounding would cause the inflation rate to rise slightly and boost federal government outlays by $\$ 1$ billion per year or more. This conclusion is mistaken because, as shown above, there appears to be essentially no "rounding tax." Even if there were a "rounding tax," however, the calculation would be incorrect because eliminating the penny would at most (according to Lombra's calculations) introduce a one-time increase in prices of about 1/100 of one percent. Such a small increase wouldn't generally affect the Consumer Price Index (CPI), which isn't calculated this precisely. The Bureau of Labor Statistics reports the CPI with only one decimal point. For example, in January, 2006 the CPI for all urban consumers was $198.3(1982-84=100)$. A $1 / 100^{\text {th }}$ of one percent increase would boost it to 198.31983 , but the BLS would round this to 198.3 , so there would be no change. A $1 / 100^{\text {th }}$ of one percent increase would have only about a one-in-five chance of boosting the index to the next significant digit. Several federal expenditures and revenues streams, such as Social Security and the income tax code, are indexed to the CPI, but they calculate the inflation rate to the tenths digit, so a $1 / 100^{\text {th }}$ of one percent increase would have only a one-in-ten chance of changing the official inflation rate in one year, under Lombra's scenario.

More importantly, the elimination of the penny would not stop prices from being quoted in cents and non-cash payments - which are now more common than cash payments [Dove Consulting, 2005] - could and would still be made in cents, so the prices recorded by the BLS wouldn't change at all, nor would its calculation of the CPI. ${ }^{6}$

\section{IMPACT ON PROFITS AND COSTS}

Lombra also concludes that rounding could hurt firms by squeezing their thin profit margins as it undermines the penny's role in theft deterrence, boosts the costs of retraining workers and spurs costly non-cash transactions. In response, sellers will react strategically and raise prices.

Chande and Fisher [2003, 517] acknowledge that retailers could act strategically, if they knew how frequently different combinations of items are purchased, but conclude that the amount gained per transaction "would be so trivially small as to have little impact" on consumer behavior and welfare. Just as importantly, the convenience store market is very competitive, so any change that affects all the firms in the market - such as eliminating the penny - would have virtually no effect on their profit levels. Profits will tend to the normal level both with and without pennies. In competitive industries prices reflect costs, so prices would rise only if costs rise. 
In addition, it is unlikely that pennies and final-digit nines have much of a theftdeterrent role currently - because of taxes, few in-store transactions ever come out to an exact dollar amount. ${ }^{7}$ Likewise, today's technology thwarts the kind of employee theft that pennies may have once deterred - theft via the employee failing to register the sale and pocketing the cash, which may be thwarted by the need to make change. In most convenience stores such a ploy would be fairly obvious since customers are conditioned to seeing the sales amount displayed on the register and hearing a "blip" when each item is scanned. They often look to see if the register rang up the correct amount, which is rarely marked on the package anymore.

The costs of retraining employees to operate in a penny-less economy, if they exist at all, are likely to be minor. The employee need only follow standard procedure, scanning items and waiting for the register to calculate how much is owed and how much change is due. Countering any temporary learning costs, the elimination of pennies would save a modicum of time spent fumbling with change - by both the customer and the clerk - increasing efficiency. Across the twenty stores in this sample, 36.3 percent of the transactions involved returning pennies in change. If the use of a penny adds even one second to the transaction time, this represents 67,480 seconds or 18.74 hours of time for the clerk, the customer, any companions of the customer and anyone in line. Average wages of retail clerks in 2004 were $\$ 9.39$ per hour or 0.26 cents per second [Bureau of Labor Statistics, 2005]. Using this wage, the value of lost time from dealing with pennies among the clerks at these twenty stores totaled $\$ 175.97$, which dwarfs the estimates of the gains or losses from rounding. The average overall wage (2004) was $\$ 18.09$ per hour or 0.5025 cents per second, so the cost of the customers' time wasted was $\$ 339$ in this sample. Applying these rates to Lombra's estimate of 106 billion transactions nationally each year and using the above estimates that 36.3 percent of transactions involve returning pennies and that returning a penny requires about one extra second, this implies that the value of wasted time is 106 billion seconds $\times 0.363 \times(0.26+0.5025$ cents per second $)=\$ 293.4$ million. This sum is fairly small - equaling about $\$ 1$ per person per year - but it understates the cost somewhat because it omits the impact on companions and others in line who have to wait and it omits cases where pennies are tendered by the customer. If use of pennies adds 2.5 seconds to the average transaction, these losses reach $\$ 733.5$ million per year. ${ }^{8}$

Whether or not the elimination of pennies leads to a greater number of non-cash transactions is an open question, but the marginal cost of such transactions has become low enough that more and more retailers have voluntarily adopted credit and debit payment for low-value transactions - even in fast food restaurants and vending machines.

One reason given for the ubiquity of prices ending in nines is that they fool some customers into thinking the item is substantially cheaper than it really is. Apparently the gap between 99 cents and one dollar just seems larger than the gap between $\$ 1.00$ and $\$ 1.01$ to some customers. With the elimination of the penny, the perception that 99 cents is substantially less than one dollar might erode, so retailers may gradually abandon the use of final-digit nines. ${ }^{9}$ However, after the Netherlands began requiring retailers to round prices to the nearest zero or five cents, retailers continued the practice of ending most prices with nine [Tiplady, 2004]. 


\section{IMPACT ON SEIGNIORAGE}

Lombra's final point is that eliminating the penny will cost the U.S. Mint substantial seigniorage each year. The Mint reported seigniorage from pennies of $\$ 24.6$ million for fiscal 2001 but since the publication of Lombra's article these figures have fallen substantially - to $\$ 8.8$ million in 2002 , $\$ 1.0$ million in 2003 and $\$ 4.6$ million in 2004. However, it is not clear that these calculations are accurate because the Mint allocates overhead costs across its coins and the portion allocated to pennies is a very small fraction. ${ }^{10}$ A more realistic share of overhead attributed to pennies would wipe out seigniorage from them completely. ${ }^{11}$

Recent events have substantially undermined the argument that the penny should be maintained because of the profit it generates for the Mint. By any accounting the Mint will show negative seigniorage from pennies for 2005 and 2006 - and it is likely to do so well into the future. The price of zinc, which comprises 97.5 percent of a penny, averaged about 35 cents per pound in 2002 and much of 2003 , rose to 45 cents at the end of 2003 , passed 60 cents in early 2005 , then exploded to $\$ 1.50$ per pound in mid 2006 and $\$ 2.00$ near the end of the year [Kitco Base Metals, 2006]. In mid-November 2006 the value of the metal in a penny equaled 1.1 cents. Analysts at the International Monetary Fund blame the wider surge in metals prices on strong international demand, especially from China. Although, they foresee a fall in these prices as the supply curve becomes more responsive, positive seigniorage on pennies will only return if the cost of the metal content falls back to at least the level of early 2003 , but based on estimates for more widely used metals, like copper and aluminum, this seems unlikely to occur by the end of the decade [IMF, 2006].

In addition, the Mint's seigniorage calculation omits part of the cost of producing pennies. It counts only the cost of distributing pennies from the Mint to the Federal Reserve. The Federal Reserve's cost of distributing pennies across the nation is likely to be several-fold higher than the Mint's distribution cost ( $\$ 2$ million), but it isn't counted against the penny in the standard calculation of the government's profit from pennies. Chande and Fisher [2003] estimate the entire distribution costs of Canadian pennies to be several times higher than the revenue from selling pennies, calculating that in 2001 the cost of manufacturing and distributing the one-cent coin was 3.95 cents per coin. These figures are likely to be fairly similar for the United States.

Finally, seigniorage (or losses) from the penny shouldn't be viewed in isolation. Eliminating the penny could be associated with the replacement of the dollar bill with

a dollar coin. If the Mint were to forego its small (or negative) seigniorage from the penny, it could probably earn substantially more seigniorage from the dollar coin. Overall annual budgetary savings - including production and processing costs, seigniorage revenue, start-up, and advertising cost - of switching from a paper to metal dollar have been estimated at more than $\$ 500$ million [GAO, 2000].

\section{CONCLUSIONS}

Recently, N. Greg Mankiw [2006] listed eliminating the penny as one of seven New Year's resolutions that politicians should make: "This year I will vote to eliminate the penny. The purpose of the monetary system is to facilitate exchange, but I have to 
acknowledge that the penny no longer serves that purpose. When people start leaving a monetary unit at the cash register for the next customer, the unit is too small to be useful. I know that some people will be upset when their favorite aphorisms become anachronistic, but a nickel saved is also a nickel earned."

Days later Mark W. Weller [2006], Executive Director of Americans for Common Cents, rebutted Mankiw citing the contention that consumers would be hit with a "rounding tax" totaling hundreds of millions of dollars annually and surveys that 70 percent of Americans want Congress to keep the penny in circulation, and that 80 percent believe merchants will use rounding as an excuse to hike prices. The primary source backing the contentions of this group (and others) that removing pennies will harm consumers is Lombra's paper [Americans for Common Cents, 2002].

My findings, however, suggest that rounding of current prices would not generate a "rounding tax." Would merchants respond to the penny's elimination by hiking prices? Looking at current prices cannot answer this question conclusively, but strongly suggests that merchants will not. Mankiw's contention that the penny has become useless is an important one. Ironically, since the half-penny was eliminated in 1857 , consumer prices have risen more than twenty-fold [Williamson, 2005], so that the half-penny of 1857 is the equivalent of today's dime, having a value of 11.3 cents in 2006 dollars. In 1857 the average nominal wage for common labor was $\$ 1.01$ per day [Margo, 2000, Table 3A.5]. Since the workday averaged about eleven hours, hourly pay was about 9.2 cents. Thus, the half-penny equaled about $1 / 18^{\text {th }}$ of the hourly pay. The equivalent fraction of today's federal minimum hourly wage is 23.6 cents. By this metric, the half-penny was worth almost the same as a quarter in today's economy. It is paradoxical that few complained about the elimination of the half-penny in 1857 , yet there is so much concern about the loss of today's penny - whose relative value is only $1 / 10^{\text {th }}$ to $1 / 20^{\text {th }}$ as much.

My conclusion is that the U.S. Mint should stop producing pennies. The U.S. government is losing money on penny production and in light of my findings, it appears that very little would be lost from eliminating the penny from the U.S. economy and more could be gained. However, individuals have the ability to use whatever they wish as money. If they wanted to continue using pennies, they could do so using the accumulated stock of pennies after the U.S. Mint discontinues minting the penny.

\section{NOTES}

I thank Charlie Sweigart, Ron Padget, and Susan Flynn for helping me obtain the data used in this analysis.

1. In addition some states exempt food from sales tax but allow localities to levy taxes on food. Adding these states to those completely exempting food from taxes boosts the percentage of the population living in states without a food sales tax to as much as 79.2 percent.

2. The transactions took place between July 17 and July 23, 2005. I omitted a small percentage of the data that were obviously anomalous - those for which pre-tax or post-tax amounts were less than zero and for which the tax rate was negative or higher than plausible.

3. Notice that 54.1 percent of the transactions involved change being returned. This may imply that Lombra's lower bound estimate (50 percent) of the percent of transactions involving cash is closer to the mark. Looking more broadly, beyond just convenience stores, a survey for the American Bankers Association (Dove Consulting, 2005) estimates that cash is used in 33 percent of in-store purchases. 
4. Change is sometimes returned from debit/credit transactions, but the amounts almost universally are whole dollars, so if some of these exist in the data set, they won't affect the rounding amounts.

5. One reason that customers may gain slightly from rounding in this data set is that they occasionally inadvertently miss their intended mark when pumping gas - for example, aiming to pump $\$ 10.00$ but inadvertently pumping $\$ 10.01$ or $\$ 10.02$. If the penny were eliminated, consumers would have more of an incentive to do this, but gasoline retailers would certainly respond with strategies that make it more difficult to accomplish - such as slightly boosting the price of gasoline.

6. In addition, almost none of the federal government's payments are made using cash, so it won't be affected by the "rounding tax."

7. Ironically, gasoline sellers do have many sales that end in exact dollar amounts - because customers so often pump an exact dollar amount of gas - but the opportunity for employee theft due to this is not considered to be a significant problem.

8. Many Internet sites report a study by the National Association of Convenience Stores and the Walgreen's drug store chain, which found that handling pennies adds 2 to 2.5 seconds to each cash transaction. I have been unable to locate this study, however.

9. Interestingly, the nation's largest retailer, Wal-Mart, has already moved away from this strategy.

10. For example, in fiscal 2004 the Mint's total "selling, general and administrative" costs equaled $\$ 88.9$ million. 64.8 percent of this was allocated to quarters, 28.8 percent to dimes, 0.9 percent to nickels, and only 1.1 percent to pennies, despite the fact that pennies represented 22.3 percent of cost of goods sold and 3.2 times as many pennies were produced as quarters.

11. Likewise, the Mint appears to have recently redefined its cost breakdown to make the penny look more profitable than it is. In fiscal 2001, when the penny was more profitable, the Mint counted "general and administrative" costs for pennies as $\$ 3.7$ million. In fiscal 2004, it counted "selling, general and administrative" costs for pennies as only $\$ 1.0$ million - as the quantity of pennies sold fell by 44 percent, its overhead costs were calculated to have fallen by 73 percent. In fact, overhead costs assigned to pennies fell by more than 50 percent from 2003 to 2004, although revenue from pennies increased.

\section{REFERENCES}

Americans for Common Cents. Penny Research. http://www.pennies.org/research.html, accessed February 23, 2006.

Bureau of Labor Statistics. National Compensation Survey: Occupational Wages in the United States, July 2004. Washington, DC, 2005.

Chande, D. and Fisher, T. Have a Penny? Need a Penny? Eliminating the One-Cent Coin from Circulation. Canadian Public Policy, 2003, 511-17.

Dove Consulting. Consumer Payment Preference: Understanding Choice. www.aciworldwide.com/pdfs/ consumer_payment_preferences_trend.pdf, 2005.

Federation of Tax Administrators. State Sales Tax Rates. http://www.taxadmin.org/fta/rate/sales.html, accessed February 23, 2006.

General Accounting Office. Financial Impact of Issuing the New \$1 Coin. Washington, DC, 2000.

International Monetary Fund. The Boom in Nonfuel Commodity Prices: Can It Last? World Economic Outlook, September 2006, Chapter 5.

Kitco Base Metals. http://www.kitcometals.com/charts/zinc_historical.html, accessed November 15, 2006.

Lombra, R. Eliminating the Penny from the U.S. Coinage System: An Economic Analysis. Eastern Economic Journal, 2001, 433-42.

Lotz, S. and Rocheteau, G. The Fate of One-Dollar Coins in the U.S. Federal Reserve Bank of Cleveland, October 15, 2004.

Mankiw, N. G. Repeat after Me. Wall Street Journal, January 3, 2006.

Margo, R. Wages and Labor Markets in the United States, 1820-1860. Chicago: University of Chicago Press, 2000.

Tiplady, R. Small Change, Big Annoyance in Europe. Business Week Online. September 23, 2004.

United States Mint. Annual Report. Washington, DC, 2002 and 2004, http://www.usmint.gov/about_the_ mint/index.cfm?action=annual_report

Weller M. A Penny for Your Economy. Wall Street Journal, January 11, 2006, A15.

Williamson, S. What Is the Relative Value? Economic History Services, December 14 2005, http://eh.net/ hmit/compare/, accessed February 23, 2006. 